\title{
位相共役光ファイバ通信システム
}

\section{菊池 和朗*}

（1996 年 4 月 8 日 受理)

\section{Optical Fiber Communication System Using Optical Phase Conjugation}

\author{
Kazuro KIKUCHI*
}

(Received April 8, 1996)

\begin{abstract}
In a long-distance optical amplifier chain, the waveform distortion is induced both by the Kerr nonlinearity and the group-velocity dispersion of optical fibers. To cope with this problem, the optical communication system using mid-span optical phase conjugation has been proposed and experimented with. In this paper, after reviewing the methods for combating with such waveform distortion, we describe the principle of the system using optical phase conjugation. The proper design for the amplifier spacing and the dispersion value of transmission fibers is necessary to improve the distortion compensation efficiency. Some examples of system design are shown, and the feasibility of practical optical phase conjugators is briefly discussed.
\end{abstract}

Key Words: Optical fiber communications, Optical phase conjugation, Optical parametric effect, Group-velocity dispersion, Kerr effect

1.はじめに

エルビウムドープ光ファイバ増幅器(ErbiumDoped Optical Fiber Amplifier: EDFA)を直接光中 継器として用いた, 長距離光ファイバ伝送シス テムが実用化されつつある。このような光増幅 中継系では, 中継器間に扔けるファイバの損失 が増幅器の利得により繰り返し補償されるため, $\mathrm{S} / \mathrm{N}$ 比の劣化による伝送距離制限は大幅に緩和さ
れる。しかしそれにかわって, 光ファイバの3次 非線形光学効果(カー効果)による伝送波形歪が伝 送距離を制限する要素となってきた。

光ファイバの非線形性が無視できる場合には, 光ファイバ伝送路の群速度分散の総量が 0 であ れば伝送波形歪は生じない。しかし長距離の光 増幅中継系では信号光パワーが光ファイバ全長 にわたって高いレベルに維持されるため, 光 ファイバのカー効果が無視できなくなる。カー 
効果による波形歪を補償する万法として, これ まで3つの提案がなされている。第一は分散マ ネージメント法である1)。この方法は, 伝送用光 ファイバの総分散を 0 に保ったまま分散分布を 長手方向に変化させ，分散の効果により非線形 効果を減殺する手法である。第二は光ソリトン 伝送方式である2)。この方式では，ソリトン光パ ルスを用いることにより分散による波形歪と非 線形効果による波形歪を釣り合わせる。この釣 合をシステム全長にわたって維持できれば，安 定な光パルス伝送が可能となる。第三は本論文 で述べる位相共役を用いた光通信システムであ る3,4)。光増幅中継伝送路の中点で信号光の位相 共役(複素共役)をとることにより, システム前半 における分散と非線形効果の蓄積を後半におい て補償することができる。

本論文ではまず第2章で,ファイバの非線形性 と群速度分散によって生じる光パラメトリック 効果の概要を伝達関数を用いた解析により示す。 第3章では,ソリトンを用いずにほぼ完全に光パ ラメトリック効果を抑圧する手法である位相共 役光通信システムについて説明し，その動作原 理を明らかにする。次に4章において, 本システ ムを有効に動作させるためのシステム設計の概 要について述べる。さらに第 5 章において, 位相 共役デバイスについて簡単にふれる。

\section{2. 光ファイバ中での光パラメトリック効果と その抑圧手法}

本章ではまず，Kerr効果と群速度分散を持つ 光ファイバ中を伝搬する光波の同相変調および 直交変調に対する基本方程式に基づき，光パラ メトリック効果の振る舞いを明確にする5)。分散 と非線形性の影響下における光電界の複素振幅 $A$ の伝搬特性は, 次の非線形シュレーディンガー 方程式で記述される2)。

$$
\frac{\partial A}{\partial z}=-\frac{1}{2} \alpha A-\frac{i}{2} \beta_{2} \frac{\partial^{2} A}{\partial T^{2}}+i \gamma|A|^{2} A
$$

$\alpha$ は伝搬損失, $\gamma$ は $\gamma=2 \pi n^{(2)} / \lambda A_{\mathrm{eff}}$ で定義される 非線形係数で， $n^{(2)}$ は非線形屈折率， $A_{\mathrm{eff}}$ は有効 コア断面積を示す。また， $\beta_{2}$ は群速度分散パラ
メータである。ここで光増幅中継系での光パラ メトリック効果を直観的に理解するために, 光 増幅中継系での光パワーの周期的変化を平均值 $\bar{P}$ で置き換える近似を用いる。このとき光ファ イバに入射された $\mathrm{CW}$ 光はカー効果による位相 回転を受け, $A=\sqrt{\bar{P}} \exp [i \gamma \bar{P} z]$ のように振る舞う。 次にこの光電界に,

$$
\begin{aligned}
& A=\{\sqrt{\bar{P}}+a\} \exp [i \gamma \bar{P} z] \\
& a(z, T)=\left\{a_{\mathrm{m}}(z)+i b_{\mathrm{m}}(z)\right\} \cos \left(\omega_{\mathrm{m}} T\right)
\end{aligned}
$$

のように角周波数 $\omega_{\mathrm{m}}$ で振動する摂動 $a$ が加わっ たとする。 $a_{\mathrm{m}}(z)$ は搬送波と同相の(In-Phase)变調 成分を， $b_{\mathrm{m}}(z)$ は搬送波と直交する(Quadrature)変 調成分を表す。同相変調は搬送波に対する振幅 変調に対応し, 直交変調は搬送波に位相変調を 誘起することは容易にわかる。式(1)(2)(3)より $a_{\mathrm{m}}$ $(z), b_{\mathrm{m}}(z)$ に対する微分方程式

$$
\begin{aligned}
& \frac{d a_{m}}{d z}=-\frac{1}{2} \beta_{2} \omega_{\mathrm{m}}^{2} b_{\mathrm{m}} \\
& \frac{d b_{m}}{d z}=\frac{1}{2} \beta_{2} \omega_{\mathrm{m}}^{2} a_{\mathrm{m}}+2 \gamma \bar{P} a_{\mathrm{m}}
\end{aligned}
$$

を得る。式(4)および(5)の物理的意味は明確であ る。 $\beta_{2}$ を含む項は，Fig. 1 に示すように搬送波 フェーザ先端にのった同相変調成分と直交変調


Fig. 1 Evolution of the complex amplitude of optical field under the influence of the group-velocity dispersion and Kerr effect in optical fibers. 
成分を回転させ，同相変調と直交変調を混合さ せる。一方 $\gamma$ 含む項は，カー効果を示す。すな わち Fig. 1に示すように, 同相変調がファイバの 屈折率变化を介して直交変調を誘起する。

次に入力端で同相変調 $a_{\mathrm{m}}(0)$ を加えたとき, 出 力端での同相変調は $a_{\mathrm{m}}(z)$, 直交変調は $b_{\mathrm{m}}(z)$ に変 化する。式(4)(5)を用いて, 伝達関数 $T_{\mathrm{a}}=a_{\mathrm{m}}(z) /$ $a_{\mathrm{m}}(0), T_{\mathrm{b}}=b_{\mathrm{m}}(z) / a_{\mathrm{m}}(0)$ は以下のように求められ る。

$$
\begin{aligned}
T_{\mathrm{a}}\left(\omega_{\mathrm{m}}\right)= & \cos \left[\frac{\beta_{2} \omega_{\mathrm{m}}^{2}}{2}\left(\frac{\beta_{2} \omega_{\mathrm{m}}^{2}}{2}+2 \gamma \bar{P}\right)\right]^{\frac{1}{2}} z \\
T_{\mathrm{b}}\left(\omega_{\mathrm{m}}\right)= & {\left[\frac{\left(\frac{1}{2} \beta_{2} \omega_{\mathrm{m}}^{2}\right)}{\left(\frac{1}{2} \beta_{2} \omega_{\mathrm{m}}^{2}\right)+2 \gamma \bar{P}}\right]^{-\frac{1}{2}} } \\
& \sin \left[\frac{\beta_{2} \omega_{\mathrm{m}}^{2}}{2}\left(\frac{\beta_{2} \omega_{\mathrm{m}}^{2}}{2}+2 \gamma \bar{P}\right)\right]^{\frac{1}{2}} z
\end{aligned}
$$

$T_{\mathrm{a}}$ は入力された同相変調の出力端での変化を, $T_{\mathrm{b}}$ は入力された同相変調が出力端で直交変調に 変化する度合いを示すので, 理想的な伝達関数 は全带域にわたって $T_{\mathrm{a}}=1$ および $T_{\mathrm{b}}=0$ である。 Fig. 2 に, $n^{(2)}=3.2 \times 10^{-20} \mathrm{~m}^{2} / \mathrm{W}, A_{\mathrm{eff}}=50 \mu \mathrm{m}^{2}$, $\lambda=1.55 \mu \mathrm{m}, D=-\left(2 \pi c / \lambda^{2}\right) \beta_{2}=-4$ (正常分散 $(a)$ ), +4 (異常分散(b)) ps $/ \mathrm{km} / \mathrm{nm}, \alpha=0.2 \mathrm{~dB} / \mathrm{km}, L=$ $2,500 \mathrm{~km}, \bar{P}=0 \mathrm{dBm}$ の条件下に扔ける伝達関数 を示した。サイドバンド周波数が高いときには 非線形効果は分散により抑圧され， $a_{\mathrm{m}}$ および $b_{\mathrm{m}}$ は $z$ 方向への伝搬に伴って正弦波状にパワーをや りとりするが, 全パワーは保存されている。しか しサイドバンド周波数が低い領域では， $a_{\mathrm{m}}$ ある いは $b_{\mathrm{m}}$ のパラメトリック増幅が起きている。特 に異常分散領域 $\left(\beta_{2}<0\right)$ ではパラメトリック増幅度 は大きい。この非線形効果は変調不安定と呼ば れる。

このように非線形性が強い領域では搬送波が ポンプ光として働き, サイドバンドに扔いてパ ラメトリック利得が生じる。この効果は変調信 号のスペクトルを変形させるので, 非ソリトン 系のシステムにおける伝送波形歪の原因となる。 これに対して分散性の領域では同相変調と直交
変調は混じりあうものの, 搬送波からサイドバ ンドへのパワーの移行は生じない。このように 分散が 0 でなければ, 非線形効果の及ぶ带域は分 散により制限されるが，一方非ソリトン系のシ ステムでは，分散による線形な波形歪みを抑え るためにシステムの総分散は 0 でなければなら ない。したがって, 非線形性を抑圧し同時に分散 も0にすることは不可能であることがわかる。

この問題を解決する手法として, ソリトン伝 送方式㧍よび分散マネージメント法が提案され ている。ソリトン伝送方式では, ある特殊な光パ

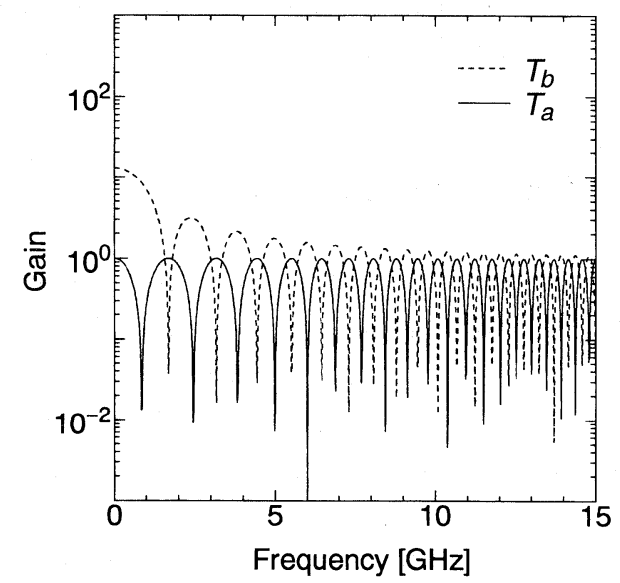

(a)

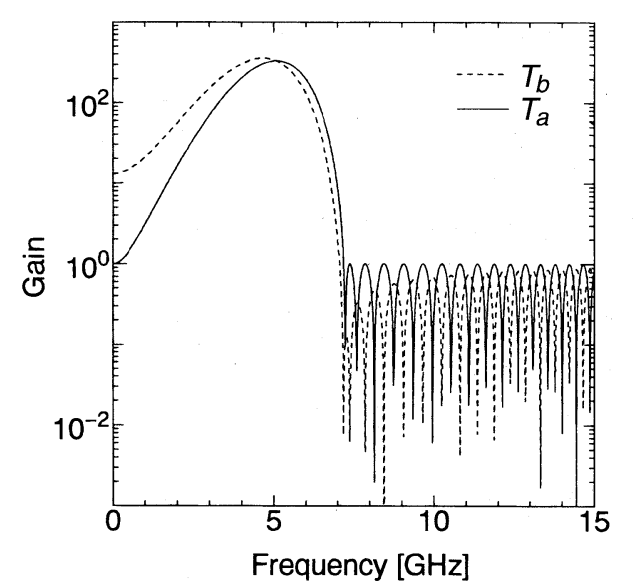

(b)

Fig. 2 Transfer functions in an optical-amplifier chain. The solid curve shows $T_{\mathrm{a}}$, and the broken curve $T_{\mathrm{b}}$. (a):normal dispersion and (b):anomalous dispersion. 
ルス波形を用いることにより分散と非線形性に よる波形歪をキャンセルさせる方式である。こ のため，システム全長にわたって分散と非線形 性の釣合を維持させる必要がある。これに対し て分散マネージメントは, 総分散は0であるが分 散を分布させることにより非線形効果の生じる 帯域を制限する方法である。Fig. 2に示すように 正常分散を用いた方が非線形効果は小さいので, 伝送用には正常分散ファイバを用い，蓄積した 分散を大きな異常分散を持つ分散補償ファイバ によって周期的に補償するというシステムが考 え得る。適当な間隔で分散補償を行えば, 非線形 効果の帯域を限定し, しかも総分散を 0 にでき る。

\section{3. 位相共役光通信システム}

第 2 章で示したように，分散マネージメント は信号帯域外に㧍ける非線形効果を抑圧する作 用を持つ。この方式は比較的容易に実現できる ので, 実用システムに導入されつつある。しかし 信号帯域内での非線形効果の蓄積を避けること はできないので, 完全な歪補償を行うことは困 難である。これに対して筆者らは, 光増幅中継系 の中点に入射光電界の複素共役を発生する位相 共役デバイスを挿入し, 光ファイバの分散と非 線形屈折率(カー効果)を同時に補償するシステム を提案した 3,4$)$ 。また渡辺らは, 伝送路中の任意 の点に位相共役器を設置したときの一般的な補 償条件を導出した6)。ソリトン伝送システムが, 光ファイバの分散と非線形屈折率に対する分布 定数的な補償法であるのに対し, 本方式は集中 定数的な補償法であると考元られる。以下に本 システムの動作原理について述べる。

式(1)の複素共役をとると

$$
-\frac{\partial A^{*}}{\partial z}=+\frac{\alpha}{2} A^{*}-\frac{i}{2} \beta_{2} \frac{\partial^{2} A^{*}}{\partial T^{2}}+i \gamma\left|A^{*}\right|^{2} A^{*}
$$

である。したがって損失と利得を反転させれば $(\alpha \rightarrow-\alpha), A(T, z)$ が非線形シュレーディンガー 方程式の解であるとき $z$ 方向に進む $A(T, z)$ の複 素共役もまた同じ方程式の解となる。

ここで入力端から光電界 $A(T, 0)$ を送出したと
しょう。伝送路の分散や非線形屈折率で歪みが 生じた出力端での信号光を, 複素共役をとった うえで入力端に逆行させると(たたし $\alpha$ の符号た けは反転させる), 入力端での光電界は $A^{*}(T, 0)$ と なる。すなわち入力端ではもとの送信波形が再 現できることがわかる。この事実は, Fig. 3(a)に 示すように伝送路の中点に位相共役器を配置し, 伝送路の前半と後半でファイバの分散分布およ び光パワー分布が中点に対して鏡像対称性を持 てば，完全な歪み補償が可能となることを意味 する。

渡辺らはこの補償原理を一般化し,つぎのよ うな補償条件を導出した。位相共役器を設置し た点を $z=0$ とし,$z=0$ から見てカー効果によ る位相回転量の等しい対称点を $-z_{1}, z_{2}$ とする。 すなわち

$$
-\int_{0}^{-z_{1}} \gamma(z) P(z) \mathrm{d} z=\int_{0}^{z_{2}} \gamma(z) P(z) \mathrm{d} z
$$

である。この対称点で

$$
\frac{\beta_{2}\left(-z_{1}\right)}{\gamma\left(-z_{1}\right) P\left(-z_{1}\right)}=\frac{\beta_{2}\left(z_{2}\right)}{\gamma\left(z_{2}\right) P\left(z_{2}\right)}
$$

の関係が満足されれば，分散とカー効果の完全 補償が可能となる。すなわち, 分散とカー効果に

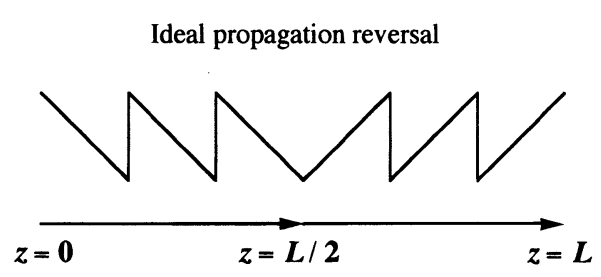

(a)

Virtual propagation reversal



(b)

Fig. 3 The ideal optical power distribution where an OPC can compensate for waveform distortion perfectly (a), and the optical power distribution in an actual system (b). 
よる位相回転量の分布が独立に鏡像対称性を持 つ必要はなく, その比が対称性をもてば十分で あることがわかる。

次に，実際にはどのようなシステムを構成す ればこの補償条件を満足できるかを検討しょう。

Fig. 3(a)の光パワー分布を実現することは不可能 であり, 実際のシステムでの光パワー分布はFig. 3(b)のようになる。しかし光増幅器間隔を十分狭 くすれば，光パワー分布は均一分布と近似する ことができる。この近似が成り立つ場合には, シ ステム前半と後半でシステム長の比を $1: d$, 光 パワーの比と分散の比をそれぞれ $d: 1$ にすれ ば，式(9)(10)に示す補償条件が満足される。な お, 光パワー分布の不均一性による補償の不完 全性については次章で論ずる。

一方，分散分布を制御する自由度が許される 場合は, 光パワーの減衰にあわせて分散值を指 数関数的に低減させれば，式(10)における $\beta_{2}(z) /$ $\gamma P(z)$ の值を一定にすることができる。この值を システム前後半で補償条件を満足するように調 整することにより，光パワーが均一分布と見な せない場合でも歪補償が可能となる。

\section{4. システム設計}

位相共役光通信システムは潜在的には長距離・ 大容量化に対応できる能力を持つ。現段階では 光位相共役を比較的短距離のシステムへ導入し た報告例が多いが 7,8$)$, ごく最近, 伝送速度 $20 \mathrm{Gbit} / \mathrm{s}$, 伝送距離 $3,000 \mathrm{~km}$ のシステム実験が行 われ，その優れた伝送性能が実証されつつあ る9)。ここでは, 位相共役光通信システムの性能 を引き出すためのシステム設計の概要について 述べる。

長距離伝送システムでは, 光パワー分布にあ わせて伝送路の分散を細かく制御することは難 しい。そこでここでは分散が均一であり, 中点に 位相共役器を置いたシステムについて考えよう。 均一なパワー分布に基づく光パラメトリック効 果は, 前章の議論で示された通り光位相共役に より完全に抑圧できるが，周期的な光パワー変 動は, ある特定のサイドバンド周波数において

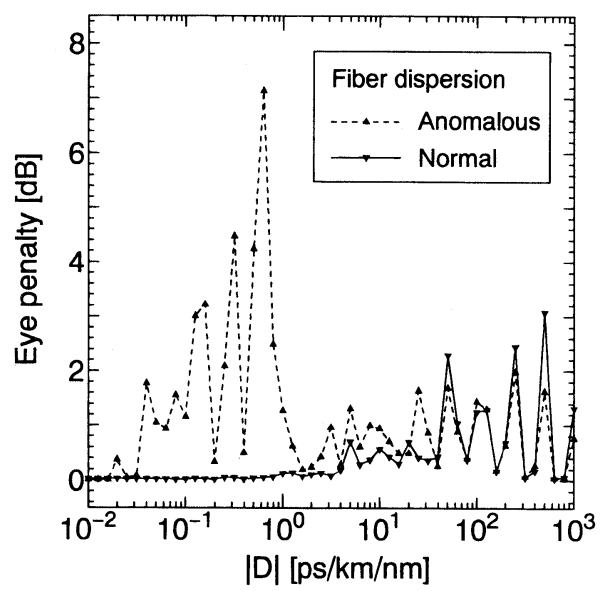

Fig. 4 Dispersion windows for suppressing the eye penalty. Note that we have a wide window in the normal dispersion region, and a relatively narrow window in the anomalous dispersion region.

サイドバンド変調不安定と呼ばれる光パラメ トリック利得を生じさせる。これによって生じ た伝送波形歪は，鏡像対称性を持たないパラメ トリック効果によるものであるから位相共役に よっても除去できず，本システムの性能限界を 支配する要因となる10)。

サイドバンド変調不安定の影響を回避するた めのシステム設計上の第一の留意点は, 中継器 間隔である。光増幅器の中継器間隔 1 は, システ 么の非線形長 $L_{\mathrm{NL}}=1 / \gamma \bar{P}$ より十分短くする必要 がある。第二の留意点は, 伝送用ファイバの分散 である。Fig. 4は, 分散によるアイ開口劣化(歪補 償度の不完全性を示すパラメー夕)の計算結果を 示したものである。計算に用いたパラメータは, $\alpha=0.2 \mathrm{~dB} / \mathrm{km}, \bar{P}=1.7 \mathrm{dBm}$, デー夕伝送速度= $40 \mathrm{Gbit} / \mathrm{s}$, 中継器間隔 $\ell=40 \mathrm{~km}$, システム全長 $=2,000 \mathrm{~km}$ である。非線形シュレーディンガー方 程式を用いて伝送された信号波形を計算するこ とにより，アイ開口劣化を評価している。正常分 散領域では広い分散領域にわたってアイ開口劣 化は小さく, 異常分散領域ではアイ開口劣化が 小さくなる分散の空が存在することが示されて いる。

異常分散領域 $\left(\beta_{2}<0\right)$ では, 変調不安定によって 広がったスペクトルがサイドバンド変調不安定 
の種になり，位相共役器によっても補償できな い歪みをもたらす。したがって, 異常分散領域に おける変調不安定の影響を避けるためには, 分 散をある程度大きくし，変調不安定の带域を信 号帯域に比べて十分狭くする必要がある。これ に対して, 正常分散領域 $\left(\beta_{2}>0\right)$ では変調不安定は 存在しないので, 分散と非線形屈折率による久 ペクトルの変化は異常分散領域ほど大きくはな い。したがって, サイドバンド変調不安定が誘起 されにくく，位相共役による歪み補償が広い範 囲で効率的に行われる。

以上の議論より，長距離伝送には正常分散領 域の利用が好ましいと言える。この領域では分 散の空は広く, 分散の変動に対して耐性がある。 一方, $1.3 \mu \mathrm{m}$ 零分散ファイバ(通常分散ファイバ)

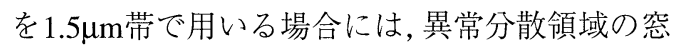
を使うことが可能である。これは, 通常分散ファ イバを用いた既存のシステムを $1.5 \mu \mathrm{m}$ 帯で用い る場合の, 伝送歪み補償技術として注目される。 光位相共役は, さらにいろいろなシステムに 適用が可能である。まず, 波長分割多重光通信シ ステムへの適用を考元よう11)。複数の波長が同 時に 1 本のファイバ中を伝搬すると，1つのチャ ンネルでの波形歪に加えてチャンネル間の非線 形相互作用によるクロストークが避けられない。 しかしこのクロストークは, 光ファイバの群速 度分散とカー効果によって生じたものであるか ら，単一チャンネルの場合と同様に位相共役に より補償できることは明かである。さらに光位 相共役は, 光ソリトン伝送の安定化にも有効で ある ${ }^{12)}$ 。本来光ソリトンは, 群速度分散抒よび カー効果の存在下で安定に伝搬する光パルスで あるが，パルス幅がサブ ps 領域になると、ソリ トンパルス間の相互作用やラマン効果などの非 線形効果の影響により, 安定な伝送が困難にな る。このような状況のもとでも伝送路の中点で 光位相共役を行えばこれらの非線形効果の影響 を補償できるので，ソリトンの安定化が可能に なる。

\section{5. 光位相共役デバイス}

光位相共役波は，縮退四光波混合を用いて発

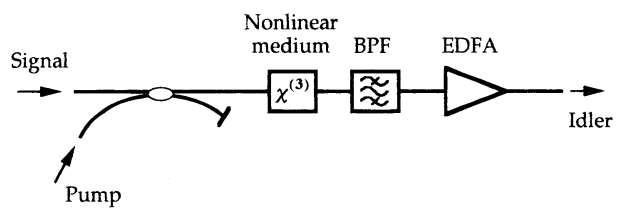

Fig. 5 Schematic diagram of phase-conjugation devices.

生させることができる。Fig. 5 にデバイスの基本 構成を示す。3 次の非線形感受率 $\chi^{(3)}$ を有する媒 質にポンプ光(角周波数 $\omega_{\mathrm{p}}$ ) と信号光 $\left(\omega_{\mathrm{s}}\right)$ とを入射 させるとポンプ光と信号光のビートが生じ， $\chi^{(3)}$ の作用により媒質中に屈折率もしくは利得変動 に基づくダイナミックグレーティングが形成さ れる。ポンプ光がこのグレーティングによって ブラッグ回折され, アイドラ光 $\left(\omega_{\mathrm{i}}=2 \omega_{\mathrm{p}}-\omega_{\mathrm{s}}\right)$ が 発生する。ポンプ光と信号光によって生じる三 次非線形分極は, ポンプ光電界を $A_{\mathrm{p}}$, 信号光電 界を $A_{s}$ とすることにより

$$
P_{\mathrm{NL}}=\chi^{(3)} A_{\mathrm{p}}^{2} A_{\mathrm{s}}^{*}
$$

で与えられる。したがってこの非線形分極によ り励振されるアイドラ光電界 $A_{\mathrm{i}}$ は, 信号光の位 相共役となることがわかる。

光通信システムへ応用するためには，位相共 役波の発生効率が高いこと, 応答速度が高速で あることが要求される。これらの要求に応える 位相共役デバイスは, 三次非線形光学材料とし て分散シフト光ファイバや半導体光増幅器を用 いて実現されているが，システムへの導入をは かるには一層の高性能化が不可欠である。

\section{6. むすび}

超長距離光伝送システムの中点で光位相共役 を行い，分散ならびに非線形効果を補償する位 相共役光通信システムに関して解説した。長距 離・大容量化のためのシステム設計理論はほぼ 確立しつつあり，実用レベルの光位相共役デバ イスの開発が現在の主たる研究課題である。光 位相共役は, 非ソリトン伝送システム,ソリトン 伝送システムの如何にかかわらず，その伝送性 能を向上させることが可能である。今後, 大規模 なシステム実験によりその有効性が実証される 
ことを期待したい。

\section{参 考 文 献}

1) N. Henmi, Y. Aoki, T. Ogata, T. Saito and S. Nakaya: J. Lightwave Technol. 11 (1993) 1615.

2) G. P. Agrawal: Nonlinear Fiber Optics (New York: Academic Press, 1989).

3) K.Kikuchi and C.Lorattanasane: Topical Meeting on Optical Amplifiers and Their Applications (OAA'93), SuC1, Yokohama, July 1993.

4) K.Kikuchi and C.Lorattanasane: IEEE Photonics Technol. Lett. 6 (1994) 104.

5) K.Kikuchi: IEEE Photonics Technol. Lett. 5 (1990) 221.

6) S.Watanabe and M.Shirasaki: J. Lightwave
Technol. 14 (1996) 243.

7) M. C. Tatham, G. Sherlock and L. D. Westbrook: Electron. Lett. 29 (1993) 1851.

8) A.H.Gnauck, R.M.Jopson and R.M.Derosier: IEEE Photonics Technol. Lett. 5 (1993) 663.

9) S. Watanabe, S.Kaneko, G.Ishikawa, A.Sugata, H.Ooi and T.Chikama: International Conference on Integrated Optics and Optical Fiber Communication (IOOC'95), PD2-6, Hong Kong, June 1995.

10) C.Lorattanasane and K.Kikuchi: IEEE Photonics Technol. Lett. 7 (1995)1375.

11) S. Watanabe: Optics Lett. 19 (1994) 1308.

12) W.Forysiak and N.J.Doran: Electron. Lett. 30 (1994) 154.

\section{レーザーワード}

\section{光位相共役 (Optical Phase Conjugation)}

光電界複素振幅の複素共役を発生させる操作。三次の非線形光学材料にポンプ光 $\mathrm{E}_{\mathrm{p}}\left(\omega_{\mathrm{p}}\right)$ と信号 光 $\mathrm{E}_{\mathrm{s}}\left(\omega_{\mathrm{s}}\right)$ を入射すると, 角周波数 $2 \omega_{\mathrm{p}}-\omega_{\mathrm{s}}$ のアイドラ光が発生する。アイドラ光の複素振幅は $\left|\mathrm{E}_{\mathrm{p}}\left(\omega_{\mathrm{p}}\right)\right|^{2} \mathrm{E}_{\mathrm{s}}\left(\omega_{\mathrm{s}}\right) *$ に比例するので，アイドラ光は信号光の位相共役波となることがわかる。

伝搬してきた光の位相共役波を同じ経路にそって戻してやると, 経路上のどの位置においても, 位相共役波の光電界は入射光の光電界の複素共役となる。したがって経路上で光電界が位相の擾 乱を受けても，位相共役波はあたかも時間を遡るように伝搬し，位相の擾乱が補償される。この 性質は，補償光学や光ファイバ通信システムに打ける分散補償に応用されつつある。

(菊池 和朗)

\section{群速度分散 (group velocity dispersion)}

群速度 (波のかたまりが伝搬する速度) が, 波長によって変化する現象。群速度分散を有する媒 質中を光パルスが伝搬すると，パルスの時間幅が広がってしまう。単一モード光ファイバでは， 群速度分散は材料自身の屈折率の波長依存性に起因する材料分散と, 導波路構造にすることに よって生じる導波路分散との和で与えられる。標準的な石英系単一モード光ファイバでは波長 $1.3 \mu \mathrm{m}$ 付近で群速度分散が零となるが, 伝搬損失が最小となる波長 $1.55 \mu \mathrm{m}$ 付近で群速度分散が零 となるように屈折率分布を工夫した分散シフトファイバが, 大容量基幹伝送路に用いられている。 